\title{
アレルギー性鼻炎の鼻閉に対するフマル酸エメダスチンの有効性
}

$$
\begin{aligned}
& \text { 宮崎総一郎 } 11) \text { 横溝 道範 }{ }^{1)} \text { - 石川 和夫 } 11 \\
& \text { 戸川 清1) } ・ \text { 山田 昌次 }{ }^{2)} \text { ・飯田 浩2) } \\
& \text { 真崎 雅和 } 3) \cdot \text { 工藤 和夫 }{ }^{3)} \text { ・松本 敏江 }{ }^{4)}
\end{aligned}
$$

\section{Effect of Emedastin Difumarate on Nasal Obstruction in Nasal Allergy}

\author{
(Akita University School of Medicine) \\ Shoji Yamada and Hiroshi Iida \\ (Yuri Kumiai Hospital) \\ Masakazu Masaki and Kazuo Kudo \\ (Akita Municipal Hospital) \\ Toshie Matsumoto \\ (Koto Hospital)
}

Soichiro Miyazaki, Michinori Yokomizo, Kazuo Ishikawa and Kiyoshi Togawa

The effect of emedastine difumarate on nasal obstruction was examined in 21 patients $(8$ males and 13 females, average age : 26.3 years) with perennial nasal allergy. The patients received $2 \mathrm{mg}$ of emedastine difumarate twice a day for one or two weeks. Objective measurement of nasal obstruction was performed by active anterior rhinomanometry using nozzle before and after treatment. Nasal resistance at the point of $\triangle \mathrm{P} 100 \mathrm{~Pa}$ in inspiration was calculated for the analysis. For the statistical analysis the paired $t$ test was applied.

The decrease in the subjective symptom score was significant. However, there was a small but not statistically significant decrease $[0.416 \mathrm{~Pa} /(\mathrm{ml} / \mathrm{sec}) \rightarrow 0.360 \mathrm{~Pa} /(\mathrm{ml} / \mathrm{sec})]$ in nasal resistance in all cases. A significant decrease $[0.500 \mathrm{~Pa} /(\mathrm{ml} / \mathrm{sec}) \rightarrow 0.307 \mathrm{~Pa} /(\mathrm{ml} / \mathrm{sec}), \mathrm{p}<0.05]$ in nasal resistance was noted in patients who had complained of slight nasal obstruction.

Our findings confirm the efficacy of emedastine difumarate in the treatment of nasal obstruction in allergic rhinitis.

Key words : emedastine difumarate, nasal allergy, rhinomanometry, nasal resistance

はじめに

アレルギー性鼻炎の主要症状の 1 つである鼻閉は，七

スタミンの関与した即時型反応のみならず，ロイコトリ

エン, 血小板活性化因子, トロンボキサン A2 等の関与

した遅発型アレルギー反応による鼻粘膜間質の浮腫によ
り形成される.フマル酸エメダスチン(商品名：レミカ ット () は抗アレルギー作用1)，抗ヒスタミン作用2)，七

スタミン遊離抑制作用 ${ }^{3)}$ ，好酸球遊走・浸潤抑制作用 ${ }^{4)}$ の薬理作用を有し, 即時型反応抑制に加えて, 遅発型ア レルギー反応も抑制する5)ことが報告されている.今回，
1) 秋田大学医学部耳鼻咽喉科学教室

3）秋田市立総合病院耳鼻咽喉科
2) 由利組合総合病院耳鼻咽喉科

4) 湖東総合病院耳鼻咽喉科 
われわれは通年性アレルギー性鼻炎の鼻閉に対するフマ ル酸エメダスチンの効果について，鼻腔通気度計を用い た客観的評価を加えて臨床評価を行ったので報告する。

\section{対象と方法}

対 象

対象は1995年 5 月から1996年 2 月の間に, 秋田大学耳 鼻咽喉科の関連病院 4 施設を受診した通年性アレルギー 性鼻炎症例である。研究対象として27例(男11名，女16 名，平均年齢 27.4 歳)が登録されたが， 6 例が除外・脱 落症例となり解析対象は21例(男 8 名, 女13名, 平均年 齢26.3歳)である. 除外・脱落症例は初診後または 1 週 間後より来院しなくなったものである.アレルギー性鼻 炎の診断にあたっては, 鼻汁中好酸球検査, 血清 $\operatorname{IgE}$ 抗体検査, 皮内テストのいずれか 2 つ上上が陽性を示し た症例を対象とした．これらの患者の主要抗原は八ウス ダスト，ダニであった．奥田6)の重症度分類では, 軽度 が 4 例, 中等度が 8 例, 重度が 9 例であった。

方 法

フマル酸エメダスチンを 1 回 1 2 $\mathrm{mg}$ を 1 日 2 回, 朝食後および就寝前に原則として 2 週間以上経口投与し た. 21 例中， $4 \mathrm{mg}$ 投与は 13 例， $2 \mathrm{mg}$ 投与は 7 例， 4 $\mathrm{mg}$ から $2 \mathrm{mg}$ に減量したもの 1 例であった. 投与開始 前には 3 日以上, 他の抗アレルギー薬を服用しないこと， 調査期間中は点鼻薬等は可能な限り使用しないこととし たが，7例で併用薬が投与された(内訳：ステロイド点 鼻薬 6 例, 抗生物質 2 例). 投与前と投与 $1 \sim 2$ 週間後 に, 自覚症状 (くしゃみ, 鼻汁, 鼻閉), 鼻内所見 (下鼻 甲介粘膜の腫脹, 色調, 鼻汁量, 鼻汁の性状), 鼻腔抵 抗值を評価した. 自覚症状, 鼻腔所見の解析にあたって は，奥田の重症度を $\# \rightarrow 3, H \rightarrow 2,+\rightarrow 1,-\rightarrow 0$ の上う にスコア化して用いた。ささらに自覚症状扣よび鼻腔抵抗 值を含めた他覚所見の改善度を以下の 5 段階で評価した。 1 : 著明改善, 2 : 改善, 3 : やや改善, 4 : 不変, 5 : 悪化. また自覚症状, 他覚所見改善度を総合し, 最終全 般改善度を同様に 5 段階で評価した。

鼻腔抵抗值の測定は鼻腔通気度計(MPR-2100, 日本 光電社製)を用い,ノズルを利用したアンテリア法で実 施した．鼻腔抵抗値の比較検討にあたっては吸気時 100 $\mathrm{Pa} /(\mathrm{ml} /$ 秒) の值を用いた。

統計解析には $\mathrm{t}$ 検定を用い, $\mathrm{p}<0.05$ を有意差ありと した.

\section{結果}

1) 自覚症状, 他覚所見重症度の推移および改善度 フマル酸エメダスチン投与前後での, 自覚症状(くし やみ，鼻汁，鼻閉)の推移を図 1 亿示寸.すべての自覚 症状スコアは 1 週間後, 2 週間後および終了時で投与前 に比し有意に低下した。他覚所見については，下鼻甲介 粘膜の腫脹, 鼻汁量ともに(図 2 ) フマル酸エィダスチン 投与により有意に減少した。自覚症状の総合改善度は著 明改善 $38.1 \%$, 改善以上 $76.2 \%$, やや改善以上 $81.0 \%$ で あった．他覚所見の総合改善度は著明改善 $15.0 \%$, 改善 以上 $55.0 \%$, やや改善以上 $75.0 \%$ であった。

\section{2 ) 鼻腔抵抗值の推移}

投与前後で通気度測定が可能であった 18 症例の鼻腔抵 抗值の平均は投与前 $0.416 \pm 0.240 \mathrm{~Pa} /(\mathrm{ml} /$ 秒 $)$ から投与 後 $0.360 \pm 0.194 \mathrm{~Pa} /(\mathrm{ml} /$ 秒 $)$ となったが，有意差は認め なかった．鼻腔抵抗值の正常上限である $0.350 \mathrm{~Pa} /(\mathrm{ml} /$ 秒)を境界として18症例を 2 群にわけて鼻腔抵抗值の推 移を見た結果を図 3 に示すが，低下傾向はあるものの有 意の減少ではなかった。しかし，自覚的な鼻閉が軽度で あった 8 症例で同様の検討をしたところ, 図 4 のように 投与前鼻腔抵抗值 $0.350 \mathrm{~Pa} /(\mathrm{ml} /$ 秒 $)$ 以上の群でフマル 酸エメダスチン投与後に鼻腔抵抗值は有意の減少を示し た.

図 5 にフマル酸エメダスチン投与前の自覚的鼻閉感と 鼻腔抵抗値の関係について示したが，両者間には相関は 認められなかった。

\section{3 ) 最終全般改善度}

自覚症状, 鼻腔所見, 鼻腔抵抗値を総合したフマル酸 エメダスチンの最終全般改善度は著明改善 $28.6 \%$, 改善 以上 $61.9 \%$, やや改善以上 $81.0 \%$ であった.

$$
\begin{gathered}
\text { 考 察 } \\
\text { フマル酸エメダスチンのアレルギー性鼻炎に対するこ }
\end{gathered}
$$
れまでの報告7)では自覚症状としてのくしゃみ，鼻汁， 鼻閉のいずれに対しても即効性があり，特に難䠌するこ とが多い鼻閉に対して高い改善度が得られている．今回 の検討で，フマル酸エメダスチンは最終全般改善度で著 明改善 $30 \%$ と良好な成績が得られ，特に自覚症状では著 明改善 $40 \%$ と高值で，鼻閉スコアも有意の減少を示した。 しかし本研究の目的であるフマル酸エメダスチンの鼻閉 に対する有効性の客観的な評価の点では症例数が少ない 関係もあるが，鼻腔抵抗值の有意な低下を全体では認め 


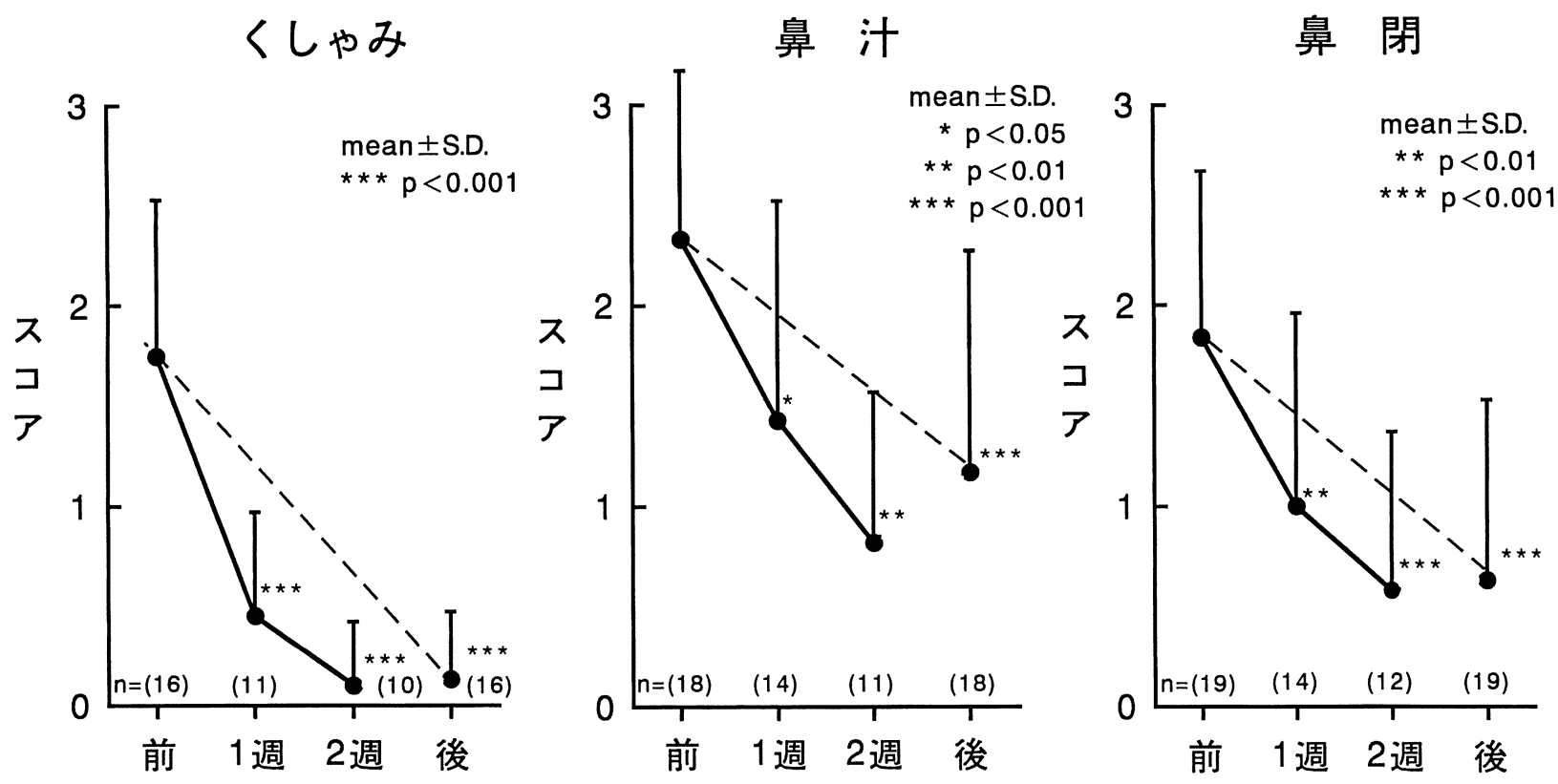

図 1 フマル酸エメダスチン投与前後での, 自覚症状(くしゃみ, 鼻汁, 鼻閉)の推移

自覚症状の解析にあたって, 奥田の重症度を州 $\rightarrow 3,+\rightarrow 2,+\rightarrow 1,-\rightarrow 0$ のららにスコア化して用いた。すべて の自覚症状スコアは 1 週間後, 2 週間後および終了時で投与前に比し有意に低下した.

下鼻甲介粘膜の腫脹

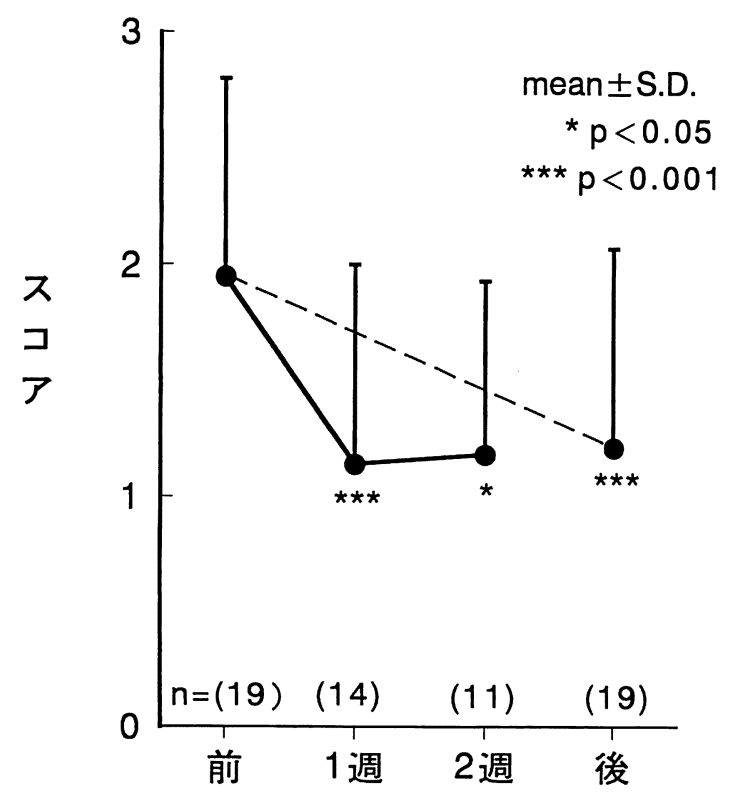

鼻 汁 量

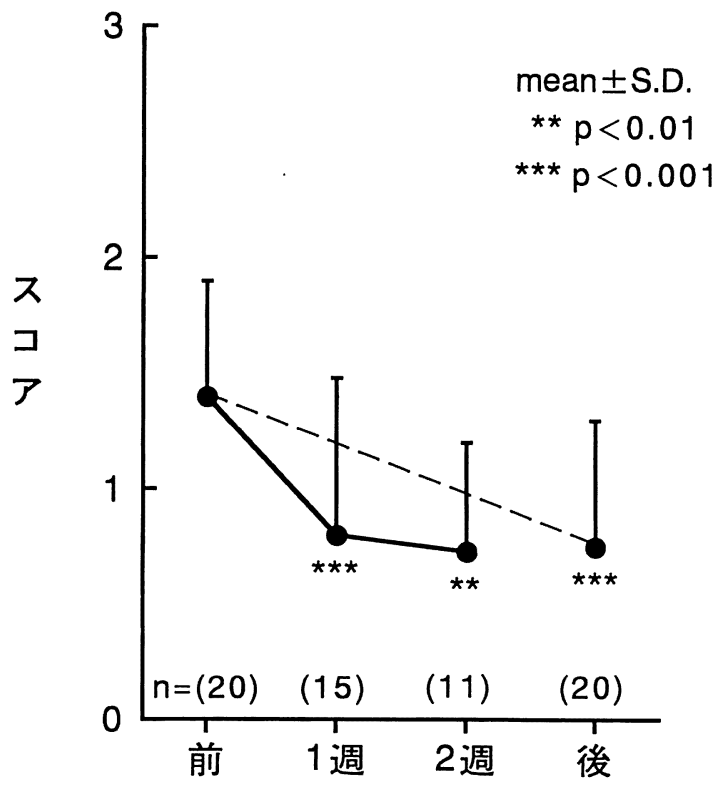

図 2 フマル酸エメダスチン投与前後での, 鼻腔所見の推移

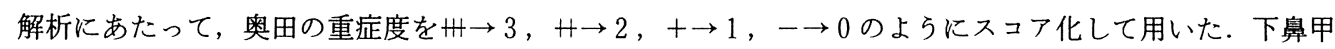
介粘膜腫脹, 鼻汁量のスコアはともに 1 週間後, 2 週間後および終了時で投与前に比し有意に低下した. 


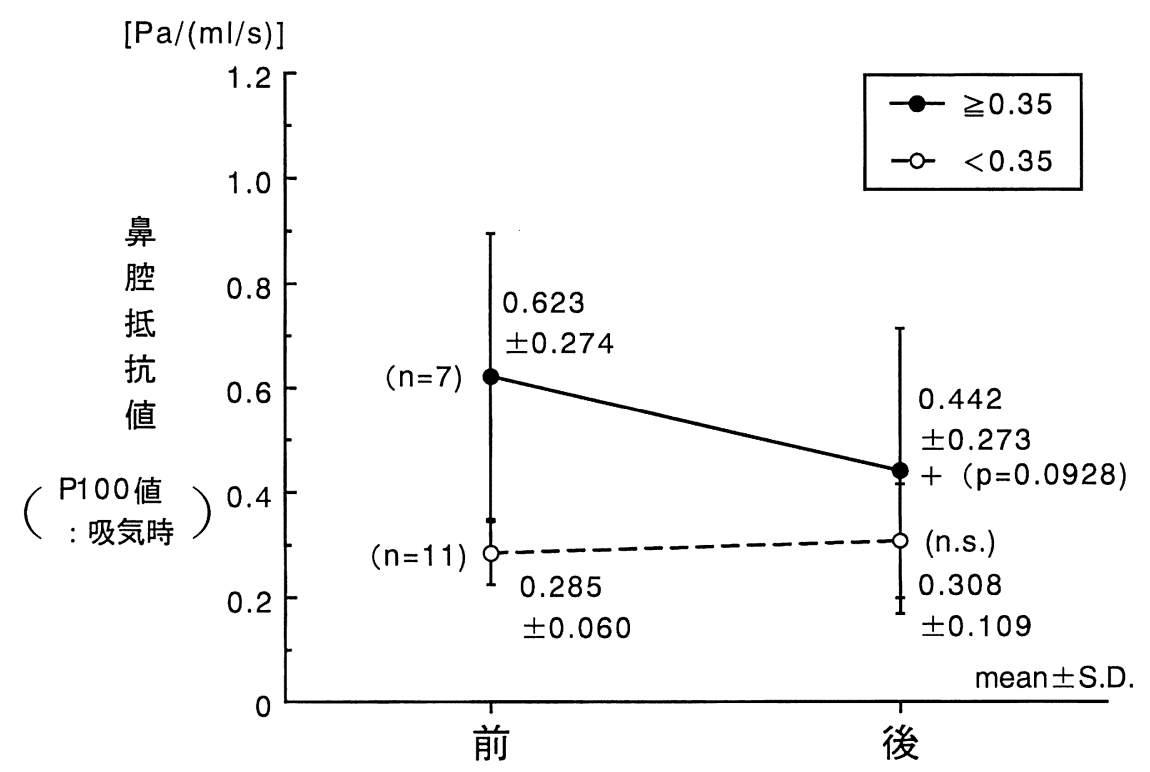

図 3 フマル酸エメダスチン投与による鼻腔抵抗值の推移

鼻腔抵抗值の正常上限である $0.350 \mathrm{~Pa} /(\mathrm{ml} /$ 秒) を境界として 18 症例を 2 群に わけて鼻腔抵抗值の推移を見たが，低下傾向はあるものの有意の減少ではなか った。

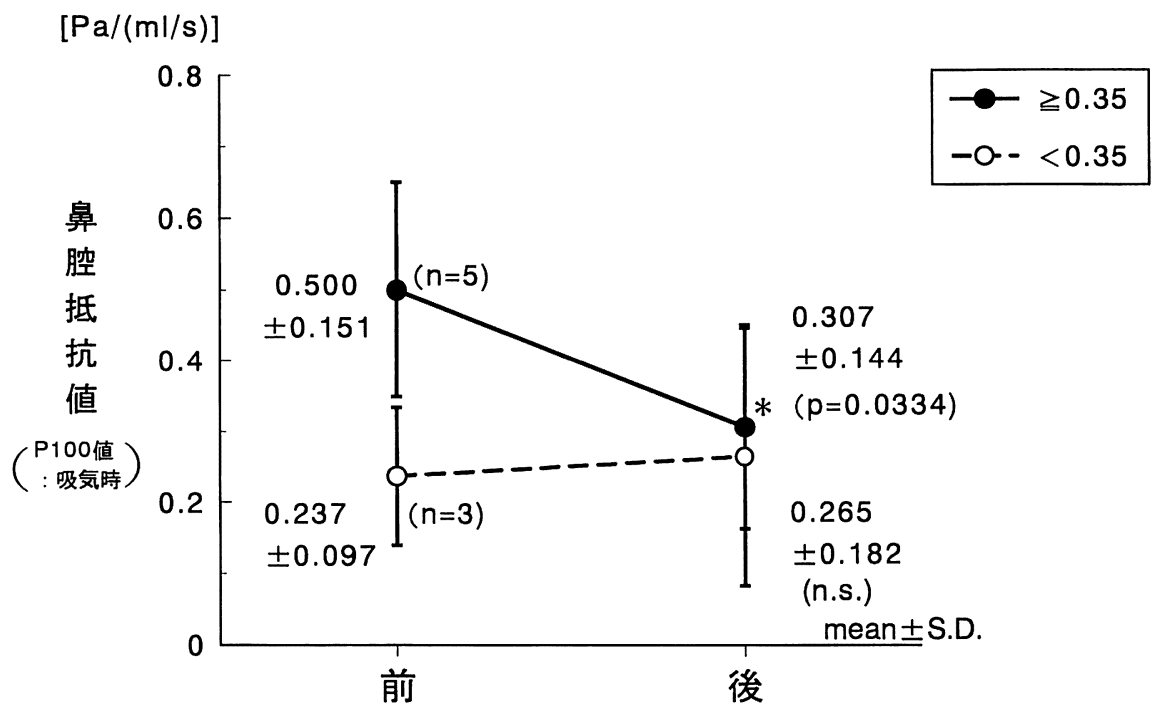

図 4 自覚的鼻閉軽度症例に批る鼻腔抵抗值の推移

自覚的鼻閉が軽度であった 8 症例で $0.350 \mathrm{~Pa} /(\mathrm{ml} /$ 秒) を境界として 2 群にわけ， 鼻腔抵抗值の推移を見た. 投与前鼻腔抵抗值 $0.350 \mathrm{~Pa} /(\mathrm{ml} /$ 秒) 以上の群でフマ ル酸エメダスチン投与後に鼻腔抵抗值は有意の減少を示した.

ることができなかった．ただし，自覚的鼻閉感の軽度症 例群では, 鼻腔抵抗值の高值例で抵抗值の有意な低下を 認めた．少数例ではあるが，その一部で鼻閉に対する有
効性を見出せたことは, フマル酸エメダスチンのI 型ア レルギー遅発反応に対する抑制効果といら基礎的な検討 結果5)を支持すると考える. 今後さらに症例を增やして 


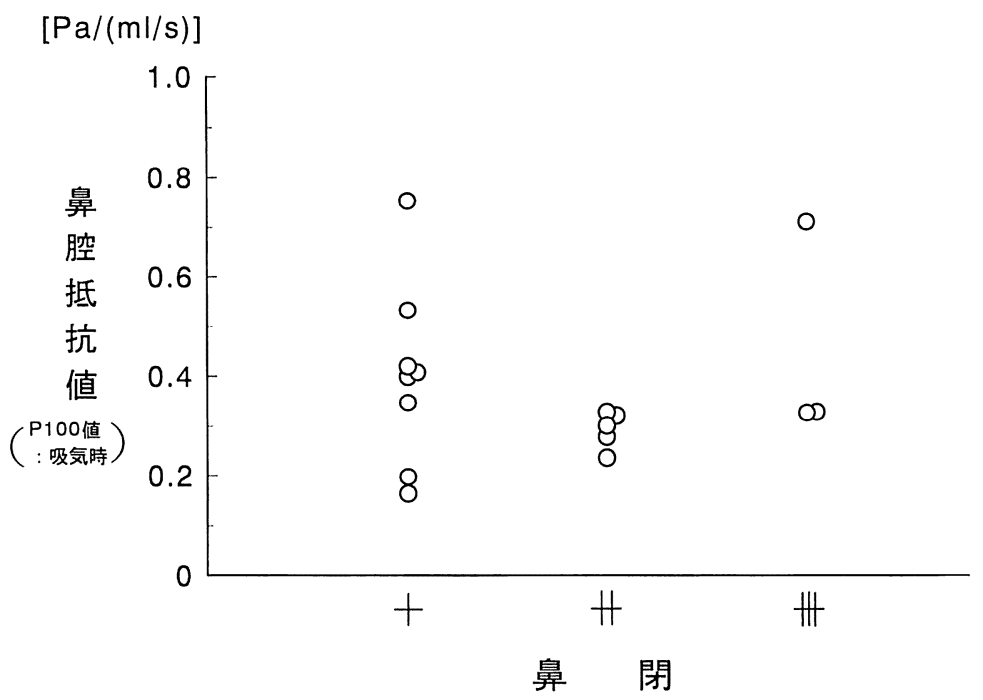

図 5 自覚的鼻閉感と鼻腔抵抗值の関係

フマル酸エメダスチン投与前の自覚的鼻閉感と鼻腔抵抗值の両者間 には，相関は認められなかった $(\mathrm{N}=16)$.

再検討与る必要がある。

一般的に，抗アレルギー剤の鼻閉に対する有効性検討 にあたって利用されるパラメータは，アレルギー日誌に よる自覚的鼻閉感の変動と鼻腔所見の変化のみであるこ とが多い.しかし自覚的鼻閉感は客観的とはいえず，ま た鼻腔所見を定量的に評価することは非常に困難である. 鼻閉の客観的評価法として代表的な方法の 1 つに鼻腔通 気度測定 ${ }^{8)}$ がある.鼻腔通気状況を客観的に把握するこ とで, 正常鼻腔通気状態とその生理的変動状況, 鼻呼吸 障害の程度, 治療の要否, 治療効果を知ることができる. しかし鼻腔抵抗值が患者の鼻閉感と必ずしも一致するも のではないとする報告910) も多い。本研究でも図 5 に示 したよらに鼻腔抵抗值と自覚的な鼻閉感との間に相関は みられず，軽度の鼻閉感しか訴えない症例で鼻腔抵抗が 高值であったり，高度鼻閉を訴えても鼻腔抵抗值の低い 例が存在していた。 しかし，鼻閉感と鼻腔抵抗值が相関 しなくても，他覚的な鼻内所見と鼻腔抵抗值はよく相関 することは忘れてはならない，薬剤の鼻閉に対する客観 的評価法には，鼻腔通気度測定以外に，新しい評価法と して音パルス反射を利用したacoustic rhinometry ${ }^{11)}$ ある．この方法ではノーズピースを介して音波を鼻腔内 に導き，その反射波を解析して鼻腔断面積を測定する. 鼻腔内の断面積から鼻腔開存性を評価できるとされてい る. acoustic rhinometry は検査手技が容易で, 被検者
に対してほとんど無侵襲であり，測定時間が短く，被検 者の協力を必要としないといった利点の多い検査である. 山際ら 12) は acoustic rhinometryを用いて, フマル酸エ メダスチン投与前後で鼻腔断面積, 鼻腔容積を求めた. その結果，フマル酸エメダスチン投与により鼻腔断面積 および鼻腔容積は投与前に比し有意に増大し，投与中止 1 週間後に拈いては有意ではなかったと報告している. また，山際ら ${ }^{13)}$ はプロピオン酸フルチカゾンの抗アレ ルギー性鼻閉効果についても acoustic rhinometryを用 いて検討し，自覚的な鼻閉感と客観的な鼻閉感に対して 確かな効果があったと報告している．その考察で，山際 らはより精度の高い他覚的評価法として，鼻腔通気度検 査に対する期待は大きいが，鼻腔通気度検査は比較的時 間を要し，検者と被検者双方の十分な訓練が必要であり， 日常臨床レベルでは繁用しがたいと述べている．確かに， 鼻腔通気度測定を上咽頭圧導出がときに困難であるポス テリア法や，マスクを用いたアンテリア法で実施すると 比較的時間を要することが多い，しかし今回我々が採用 したノズルアンテリア法では，通気度計を診察台の横に 設置しておけば，臨床医自身の手で簡便にごく短時間で 通気度測定が可能である.ノズル法は西欧人のように外 鼻孔が細く花立している場合には測定上問題となること があるが，外鼻孔が丸い日本人では実地診療レベルなら 問題ないと考える。ただしアンテリア法では一側ずつの 
抵抗値しか得られないので，総合鼻腔抵抗值は，鼻腔通 気度計に内蔵された計算機により算出される。またアン テリア法では，一側の完全鼻閉例では測定できない欠点 がある，鼻腔は自律神経の作用により，時々刻々呼吸動 態が変化しているが，鼻腔通気度検査はその客観的評価 法として有用性が認められて掞り，日常臨床での積極的 な利用が望をれる。

$$
\text { まとめ }
$$

通年性鼻アレルギーの鼻閉に対するフマル酸エメダス チンの効果について，鼻腔通気度計を用いた客観的評価 を加えて臨床評価を行った。

通年性アレルギー性鼻炎に対するフマル酸エメダスチ ンの最終全般改善度は著明改善 $28.6 \%$, 改善以上 $61.9 \%$ であった．自覚症状と他覚所見の改善度を比較すると自 覚症状改善度の方が高い改善率であった。

鼻腔通気度計により測定した鼻腔抵抗值は投与前 $0.416 \mathrm{~Pa} /(\mathrm{ml} /$ 秒 $)$ から投与後 $0.360 \mathrm{~Pa} /(\mathrm{ml} /$ 秒 $)$ と低下 傾向を認めたが，有意な変化ではなかった。しかし，自 覚的鼻閉が軽度で鼻腔抵抗值 0.350 以上の症例では, 鼻 腔抵抗值は投与後に有意な低下を示した。

\section{参考文献}

1) 斎藤忠之, 西村宣泰, 田島 滋, 他 : 1-(2-Ethoxyethl)-2-4-methyl1-homopiperazinyl)-benzimidazole difumarate (KB-2413) の抗アレルギー作用. 日薬理誌 $89: 55 \sim 62,1987$.

2 ) Fukuda $T$, Morimoto $Y$, Iemura $R$, et al : Effects of 1-(2Ethoxyethl)-2-(4-methyl-1-homopiperazinyl)-benzimidazole difumarate (KB-2413), a new antiallergic, on chemical mediators. Arzneimittel-Forschung $34: 811 \sim 815,1984$.

3 ) Saito T, Hagihara A, Igarashi N, et al : Inhibitatory effects of emedastine difumarate on histamine release. Jpn J Pharmacol 62 : 137 143, 1993.

4 ）松田直美, 斎藤忠之, 山下 明 : Platelet activating factorによるモルモット好酸球遊走に対するフマル酸エメダ スチンの作用. 薬理と治療 $21 ： 1475 \sim 1478,1993$.

5 ）成田慎一郎, 朝倉光司, 白崎英明, 他 : 鼻アレルギーモデ ルへのエィダスチンの効果. 耳鼻臨床 $89: 645 \sim 649,1996$.

6 ) 奥田 稔: 鼻アレルギーの重症度分類. 耳堠 55 : 939 945, 1983.

7 ）奥田 稔, 形浦昭克, 朝倉光司, 他 : 通年性アレルギー性 鼻炎に対するフマル酸エメダスチン (KG-2413) の臨床評価 一二重盲検群間比較試験一. 耳展 33 補 $4: 543 \sim 565,1990$.

8 ）宮崎総一郎, 戸川 清: 鼻呼吸の機能と評価法. JOHNS $12: 655 \sim 658,1996$.

9 ) Naito K, Cole P, Chaban R, et al : Nasal resistance, sensation of obstruction, and rhinoscopic findings compared. Am J Rhinol 2 : 65 69, 1988.

10) Eccles R and Jones AS : The effect of mentol on nasal resistance to airflow. J Laryngol Otol $97: 705 \sim 709,1983$.

11) Hilberg O, Jackson A, Swift D, et al : Acoustic rhinometry; evaluation of nasal cavity geometry by acoustic reflections. J Appl Physiol $66: 295 \sim 303,1989$.

12）山際幹和, 藤田健一郎：レミカット®の鼻アレルギー鼻閉 に対する効果. 耳鼻臨床 $88 ： 381 \sim 388,1995$.

13）山際幹和, 徳力俊次 : フルナーゼ®点鼻液の抗アレルギー 性鼻閉効果. 耳鼻臨床 $89 ： 1283 \sim 1291,1996$.

$$
\left(\begin{array}{l}
\text { 別刷請求先 : 宮崎総一郎 } \\
\mathbf{T} 010 \text { 秋田市本道1-1-1 } \\
\text { 秋田大学医学部耳鼻咽喉科学教室 }
\end{array}\right)
$$

